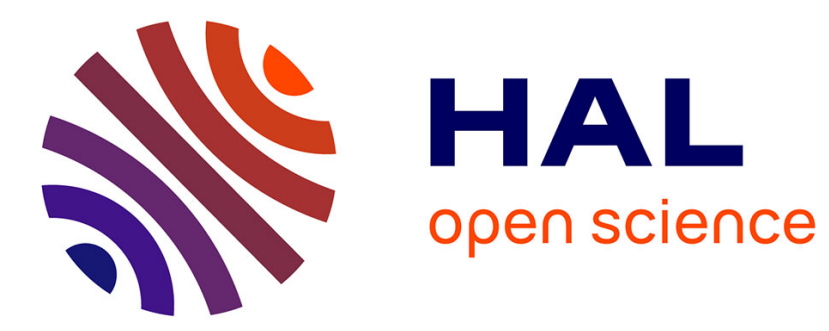

\title{
Paleotopographic control of landslides in lacustrine deposits (Trièves plateau, French western Alps)
}

Grégory Bièvre, U. Kniess, Denis Jongmans, E. Pathier, S. Schwartz, Thierry

Villemin, Cees van Westen, Vilma Zumbo

\section{- To cite this version:}

Grégory Bièvre, U. Kniess, Denis Jongmans, E. Pathier, S. Schwartz, et al.. Paleotopographic control of landslides in lacustrine deposits (Trièves plateau, French western Alps). Geomorphology, 2011, 125 (1), pp.214-224. 10.1016/j.geomorph.2010.09.018 . insu-00442203v2

\section{HAL Id: insu-00442203 \\ https://hal-insu.archives-ouvertes.fr/insu-00442203v2}

Submitted on 2 Oct 2010

HAL is a multi-disciplinary open access archive for the deposit and dissemination of scientific research documents, whether they are published or not. The documents may come from teaching and research institutions in France or abroad, or from public or private research centers.
L'archive ouverte pluridisciplinaire HAL, est destinée au dépôt et à la diffusion de documents scientifiques de niveau recherche, publiés ou non, émanant des établissements d'enseignement et de recherche français ou étrangers, des laboratoires publics ou privés. 


\section{Paleotopographic control of landslides in lacustrine deposits (Trièves plateau, French western Alps)}

Grégory Bièvre, ${ }^{\mathrm{a}, \mathrm{c}}$, Ulrich Kniess ${ }^{\mathrm{a}}$, Denis Jongmans ${ }^{\mathrm{a}}$, Erwan Pathier ${ }^{\mathrm{a}}$, Stéphane Schwartz, ${ }^{\mathrm{b},}$, Cees J. van Westen ${ }^{\mathrm{d}}$, Thierry Villemin ${ }^{\mathrm{e}}$ and Vilma Zumbo ${ }^{\mathrm{f}}$

a- LGIT/IsTerre, Université Joseph Fourier, CNRS-UMR 5559, BP-53, 38041 Grenoble cedex, France b- LGCA/IsTerre,Université Joseph Fourier, CNRS-UMR 5025, BP-53, 38041 Grenoble cedex, France

c- Centre d'études Techniques de l'équipement de Lyon, Laboratoire Régional d'Autun, BP 141, 71405 Autun cedex, France

d- International Institute for Geo-Information Science and Earth Observation (ITC), Hengelosestraat 99, 7500 AA, Enschede, The Netherlands

e- Laboratoire Environnements Dynamiques et Territoires de Montagne, CNRS, Université de Savoie, 73376 Le Bourget-du-Lac, France

f- Inexia-Ingénierie, Département Infrastructures et Aménagement, 1 Place aux étoiles, 93212 Saint-Denis-La-Plaine Cedex, France

*Corresponding author. Tel.: +33 (0)4 766359 04; Fax: +33 (0)4 765140 58; E-mail: stephane.schwartz@ujf-grenoble.fr 


\begin{abstract}
Paleotopography in Quaternary sedimentary environments can be an important factor that controls landslide movement. This study investigates the relation between paleotopography and landslide activity in two adjacent landslides in glaciolacustrine sediments located in the Trièves area (French western Alps). Although both are in slopes underlain by the same lacustrine deposits, the Avignonet and Harmalière landslides exhibit major differences in morphology and displacement rates. Through a combination of geological mapping, airborne light detection and ranging (LiDAR) data, aerial photographs, global positioning system (GPS), and seismic noise measurements, a three-dimensional impression was made of both landslides. The analysis reveals that the difference in kinematics between the two mass movements can be traced back to at least 50 years ago. The results show that the Harmalière slide, which failed catastrophically in 1981, is still much more active than the Avignonet landslide. The fear was that the Avignonet landslide might develop in a similar catastrophic manner, threatening a number of houses constructed on the landslide. A geophysical survey based on ambient noise measurements allowed us to map the base of the lacustrine clays, and the results indicate the presence of a N-S ridge of hard sediments (Jurassic bedrock and/or compact alluvial layers) on the eastern side of the Avignonet landslide. This ridge disappears when approaching the Harmalière landslide and makes a place to what can be interpreted as a NW-SE oriented paleovalley of the river Drac. We proposed that the ridge acts as a buttress that could mechanically prevent the Avignonet landslide from evolving as fast as the Harmalière. Furthermore, the NW-SE paleovalley located under the Harmalière landslide corresponds to the motion direction of the slide. Therefore, the different behaviour of the two landslides is partly controlled by the paleotopographic setting of Lake Trièves during the last Glacial Maximum extension. These results suggest a major influence of the bedrock paleotopography on the kinematics of the landslides.
\end{abstract}

Keywords: clay; landslides; Trièves plateau; French western Alps; LiDAR; GPS; aerial photographs; microtremors; differential kinematics; paleotographic control

\title{
1. Introduction
}

Landslide hazard assessment requires a thorough understanding of the internal controlling factors (soil nature and characteristics, fracturing, slope hydrology, vegetation) and of the triggering factors (rainfalls, earthquakes, erosion, and anthropogenic influence). Landslides occurring in recent soft sediments have been regularly reported to be controlled by tectonic features (Bozzano et al., 2008), lithological variations like the presence of smectite-rich layers (Ambers, 2001; Azanon et al., 2009), and hydrogeological drainage (Eilertsen et al., 2008). In several depositional conditions, soft sediments can exhibit significant variations in thickness in relation with an irregular paleotopographic surface existing at the time of deposition. This may be the case in volcanic environments where pre-eruption topography can be buried by volcanic ash or pyroclastic flow materials (Van Westen and Daag, 2005). In marine conditions, after the latest glaciation in Scandinavia and Canada, clay layers were deposited over an irregular surface made of a thin till layer on top of bedrock (Rankka et al., 2005). These areas have been affected by isostatic uplift, leaving the clay deposits located above sea level and subjected to salt leaching. This process generated quick clays that have been involved in numerous large clay slides (Lundström et al., 2009). Also, glaciolacustrine environments are famous for creating irregular clay deposits and favorable conditions for landslides in previously glaciated areas such as the Alps (Giraud et al., 1991; Jong- 
mans et al., 2009) or the Baltic Sea (Kohv et al., 2009). In mountainous areas, intensive erosion by glaciers or rivers has created numerous incisions in the topography, which has regularly been covered by soft deposits. In the black marls outcropping in the southwestern Alps (France), Flageollet et al. (2000) identified the role of the buried topography (crests and gullies) on the dynamics of the Super-Sauze earth flow. Recently, Coe et al. (2009), in the San Juan Mountains (Colorado, USA), observed that the location of several ponds in a huge fine-grained landslide, with displacement velocities ranging between $0.1 \mathrm{~m} / \mathrm{y}$ to $7 \mathrm{~m} / \mathrm{y}$, remained stationary for the last 50 years at least. They showed that the position of the ponds and the surface morphology coincided with the presence of irregularities of the basal topographic surface. The spatial variation in thickness of recent clayey sediments and the relation with the topography that existed at the time of deposition can then play an important role on landslide dynamics. However, few publications are still investigating the effect of such old erosional surfaces underneath recent soft deposits.

This study aims to investigate the importance of paleotopographic control of landslides in an area covered by glaciolacustrine sediments in the French Alps, and we attribute significant differences in geometry and kinematics observed between two adjacent landslides to variations in the erosional surface below the soft lake sediments. A combination of geological mapping, airborne light detection and ranging (LiDAR) data analysis, aerial photograph interpretation, global positioning system (GPS) monitoring, and seismic noise measurements were applied to characterize the landslide morphology and the thickness of the soft layer down to the underlying bedrock and to relate this to the different behavior of the landslides. The methods provide a threedimensional view of the soft formations and allow mapping of the paleotopography that plays a crucial role in explaining the different behavior of the landslides.

\section{Study area}

Two adjacent landslides, called the Avignonet and Harmalière landslides, were selected for this study. They are located in the Trièves area, $40 \mathrm{~km}$ south of the city of Grenoble in the French western Alps (Fig. 1). From the available data (Jongmans et al., 2009) and following Cruden and Varnes (1996), the Avignonet and Harmallière landslides can be classified as "active, very slow, wet, translational earthslide" and "complex, active, slow earth slide-earth flow", respectively. The region with a maximum altitude of $800 \mathrm{~m}$ above sea level (asl) corresponds to a large depression of about $300 \mathrm{~km}^{2}$ drained by the Drac River and its tributaries (Fig. 1). Geologically, this area is characterized by the widespread occurrence of Quaternary glaciolacustrine clays, which are highly prone to landslides (Lorier and Desvarreux, 2004). These clay landslides can develop over several slip surfaces ranging from superficial $(5$ to $15 \mathrm{~m}$ ) to deep (> $50 \mathrm{~m}$ ) (Blanchet, 1988; Jongmans et al., 2009). Slide velocities are generally low (a few $\mathrm{cm} / \mathrm{y}$ ) but can reach several meters per year in certain places. In some cases, generally after a long wet period accompanied by quick snowmelt, the slides can evolve into mudflows and velocities can reach several meters per hour. This leads to dramatic events such as the failures that occurred in Harmalière in 1981 (Moulin and Robert, 2004) and in La-Salle-en-Beaumont in 1994 (Moulin and Chapeau, 2004; see location in Fig. 1). The morphology of the Trièves area was controlled by several Quaternary glacier fluctuations, which resulted in alternating deposition and erosion phases. Figure $2 \mathrm{~A}$ presents a general view of the area, looking to the west. The Quaternary deposits are underlain by early Jurassic carbonate strata (Fig. 2B) that were folded and faulted during the Alpine orogenesis. Ancient glacial (Riss) and interglacial phases (Riss-Würm) carved the substratum and 
generated valleys partly filled with Riss-Würm alluvial deposits (Fig. 2C). This led to an irregular shape of the basement prior to the last glacial phase (Würm; -80 to $-12 \mathrm{ky} \mathrm{BP}$ ). During the last glacial maximum extension, which occurred between 22,000 to 18,000 BP (Clark et al., 2009), the Isère glacier that came from the North blocked the torrential flows from the Drac River and its tributaries, generating a large ice-dammed lake (Monjuvent, 1973) (Fig. 1). This lake was progressively filled during thousands of years by rythmic alternations of clay and silt layers originating from nearby Mesozoic marls and crystalline massifs (Huff, 1974). These laminated clays (Fig. 2D) rest either on carbonate rocks or on locally cemented, compact alluvial layers from the interglacial Riss-Würm period. The irregular shape of the basement induces strong lateral thickness variations of the paleolake infill, from 0 to more than $250 \mathrm{~m}$ (Fig. 3) (Monjuvent, 1973; Antoine et al., 1981). The top of the clay is generally found at an elevation of about $750 \mathrm{~m}$ asl (Antoine et al., 1981). Morainic deposits, which cap the clays found as far as the south of the village of Sinard, are evidence that the Würmian glacier has partly overridden the lacustrine materials (Figs. 1 and 3). In the study area, the thickness of the morainic deposits varies from 50 $\mathrm{m}$ around Sinard to a few meters in the east. At the end of the last glacial maximum, the Isère glacier withdrew, allowing the rivers to cut deeply into the glaciolacustrine deposits. This last erosion phase created the actual Drac River valley. This favoured the conditions for landslide development in the clay with a general eastward motion in the study area (Fig. 3) (Brocard et al., 2003; Jongmans et al., 2009).

The geological map and the cross section of Fig. 3 show the presence of two paleovalleys (v1 and v2) formed during pre-Würm interglacial incision phases. Paleovalley v1 is the oldest (Monjuvent, 1973; Brocard et al., 2003). Both paleovalleys are filled with locally cemented alluvial layers. They have been recognized by field observations and geophysical investigations conducted in the 1950s for the construction of the Monteynard dam (Crosnier-Leconte et al., 1953). In the study area, these erosion and deposition phases resulted in an irregularly shaped paleotopography (Fig. 3).

\section{Methods}

In order to compare the differences in geomorphological setting and dynamics of the Avignonet and Harmalière landslides, three techniques have been used: airborne light detection and ranging (LiDAR) data analysis, aerial photograph interpretation, and global positioning system (GPS) monitoring. The LiDAR data was collected in November 2006 using the Helimap ${ }^{\circledR}$ system (Vallet and Skaloud, 2004) with a Riegl laser scanner mounted on a helicopter flying about $300 \mathrm{~m}$ above the terrain, with an average density of 6 points $/ \mathrm{m}^{2}$ and an accuracy of $10 \mathrm{~cm}$ in vertical and horizontal directions. In order to derive the bare earth model excluding trees and houses, the point cloud was filtered and interpolated to a 2-m raster grid (final average point density 24 points/pixel) with the software SCOP $++^{\circledR}$ (IPF, 2004) using the "hierarchical robust interpolation method" (Briese et al., 2002). This method use a pyramidal approach based on a iterative weighted least squares interpolation step taking into account the data covariance (Kraus and Pfeifer, 1998), which is very similar to kriging, followed by a filtering step. The resulting shaded DEM is shown in Fig. 4. Shaded representations with different light angles were used for geomorphologic interpretation. The GPS campaign measurements have been performed twice a year (in April and November) since 1995 by RTM (Restauration des Terrains en Montagne) at 25 locations on the Avignonet landslide (Fig. 4), relative to three reference points located on nearby 
stable bedrock. The average standard deviation for all measured points is $6 \mathrm{~mm}$. No GPS measurements have been performed inside the Harmalière landslide, as the rapid movement made it difficult to install benchmarks over a longer time period (Malet et al., 2002; Coe et al., 2003).

To analyze movements in the past, photogrammetric scans aerial photographs from 1956, 1978, 1985, 1993, 2001, and 2003 were obtained from IGN (Institut Géographique National, France) with average resolution between $40 \mathrm{~cm} /$ pixel to $60 \mathrm{~cm} /$ pixel. The photos were orthorectified with the software Geomatica ${ }^{\circledR}$ using a DEM (IGN BD-ALTI DEM with $50 \mathrm{~m}$ spatial resolution), the calibration certificates of the utilized cameras and 56 ground control points measured in the field with differential GPS (the root mean square residual of the ground control points position after orthorectification is about $2 \mathrm{~m}$ ). The orthophotos, which have a spatial resolution about $0.5 \mathrm{~m}$, were analyzed to investigate the landslide activity through time from texture changes (Hervas et al., 2003).

The objective of the geophysical investigation was to map the thickness of the lacustrine materials in the two landslides. Recent works (Jongmans et al., 2009) have shown the existence of a strong shear wave ( $S$-wave) velocity contrast $(V s)(>3$ on average) between the soft upper layers (clays and moraines; $250 \mathrm{~m} / \mathrm{s}<V s<600 \mathrm{~m} / \mathrm{s}$ ) and the substratum made of compact cemented alluvial layers $\left(V_{S}=1250 \mathrm{~m} / \mathrm{s}\right)$ and Jurassic limestone $\left(V_{S}=2000 \mathrm{~m} / \mathrm{s}\right)$. With such characteristics, microtremor processing, based on the horizontal to vertical spectral ration technique $(\mathrm{H} / \mathrm{V}$ technique), has been proven to be one of the most robust and easy exploration tools for mapping the thickness of alluvial or lacustrine sediments (Ibs-von Seht and Wohlenberg, 1999; Delgado et al., 2000; Guéguen et al., 2007; Méric et al., 2007; Le Roux et al., 2010). Measurements were made with a single, three-component, 5-second sensor giving a flat response between 0.2 and $50 \mathrm{~Hz}$ and connected to a light seismic acquisition system (Chatelain et al., 2000). Seismic noise was recorded during 15 minutes with a $200 \mathrm{~Hz}$ sampling frequency. Data were processed with the Sesarray package (Wathelet et al., 2004). Microtremor records were cut into $30 \mathrm{~s}$ time windows, for which Fourier spectra were computed and smoothed using the technique proposed by Konno and Ohmachi (1998). The H/V spectral ratios were computed for all time windows, and the mean $\mathrm{H} / \mathrm{V}$ curve was determined with standard deviations at each site.

\section{Results}

\subsection{Analyzing the difference in kinematic behavior}

With the data sets described in the previous section, several features can be analyzed to highlight the difference in kinematics between the Avignonet and Harmalière landslides: the general orientation of the landslide, surface velocity, denuded area, headscarp evolution, and surface roughness.

Image interpretation revealed areas with bare soil ranging in size from $250 \mathrm{~m}^{2}$ to $>50,000 \mathrm{~m}^{2}$ in Harmalière related to active erosion and landslide activity. In the digital orthophotos, these zones appear as very bright pixels (see Fig. 5, top), and they were classified digitally using threshold values of brightness (Fig. 5, bottom) after manually excluding objects like rivers, lakes, agricultural fields, roads, and buildings identifiable by their characteristic geometric shapes. The headscarps of Harmalière and Avignonet, mapped from the 1956 aerial photo (before the construction of the Monteynard Dam), show that the maximum distance between the headscarps and the Drac valley is about $1.5 \mathrm{~km}$ in both cases. In Avignonet, the overall sliding direction 
follows a fan-shape pattern as evidenced by the GPS velocity vectors (Fig. 4) and by the slope directions of the main scarps. The 11-year average velocity vectors from GPS on the Avignonet landslide are oriented from N. $70^{\circ}$ E. to N. $130^{\circ}$ E. (Fig. 4), with a mean N. $100^{\circ}$ E. motion.

However, in Harmalière, the most active areas of the landslide developed along a NNW-SSE axis (Fig. 5) making a $30^{\circ}$ angle with the Avignonet global sliding direction. The percentage of denuded surface is much larger in Harmalière than in Avignonet (13\% vs. $5 \%$ in 1956, $20 \%$ vs. $3 \%$ in 1985 , and $19 \%$ vs. $3 \%$ in 2003). Only a very small active area in the south of Avignonet can be identified. The higher activity of Harmalière certainly goes back, at least, to the end of the nineteenth century (Moulin and Robert, 2004). At this date because of intense gully erosion occurring on the NW part of the Harmalière slide a significant reforestation work has been implemented by the state authorities. Since the catastrophic Harmalière failure in 1981, denuded areas are more concentrated in the eastern part of the Harmalière landslide, and the activity has been retrogressive. Morphological changes from the 1981 event can be seen in the interpretation of the 1985 orthophotos (Fig. 5) forming a NNW-SSE elongated flow mass without vegetation and also in Fig. 4 where a roughness contrast with the surrounding terrain can be noticed. The landslide body itself can be divided into a steeper upper part where erosion dominates and a smoother lower part corresponding to an accumulation zone, which has been conquered by trees again since the 1981 event (Fig. 5). Notably that the recent upslope evolution is not directed straight to the NW but has rotated clockwise to the NNE toward the Avignonet landslide.

The main headscarp of Harmalière, which has developed since the catastrophic event of March 1981, has been extended retrogressively through several events, of which the main ones were in 1988, 1996, and 2001 (Moulin and Robert, 2004). This evolution is traceable from aerial photo analysis, providing a mean regression rate of about $10 \mathrm{~m} / \mathrm{y}$ between 1981 and 2003 . These values are in agreement with ground observations (Moulin and Robert, 2004). Since 2001, the headscarp regression has started to affect the southern limit of the Avignonet landslide. A GPS measurement on the crest between Harmalière and Avignonet indicates mass displacement toward the SW, which is consistent with a faster regression of the Harmalière scarp toward the NE (Fig. 5) relative to Avignonet.

Surface roughness is also an indicator for landslide activity (Glenn et al., 2006). Analysis of surface roughness from the shaded LiDAR DEM (Fig. 4) shows differences between the Harmalière and Avignonet landslides in terms of wavelengths and amplitudes along the slope direction. In Harmalière, a characteristic small-scale roughness with wavelengths of $5-15 \mathrm{~m}$ and amplitudes of $0.5-5 \mathrm{~m}$ can be observed, as well as roughness at a larger scale with wavelengths of $80-200 \mathrm{~m}$ and amplitudes of $5-20 \mathrm{~m}$. Two representative elevation profiles along the slope direction are shown in Fig. 4B. On these profiles, the roughness has been estimated using the root-mean-square deviations, defined as the RMS difference in height between points separated by a given step-size (Shepard et al., 2001). Step sizes of 10 and $100 \mathrm{~m}$ along with the mean slope angles (see Table 1) were chosen, corresponding to small-scale and large-scale roughness at wavelengths of $10 \mathrm{~m}$ and $100 \mathrm{~m}$, respectively. In Avignonet, the roughness is higher at the toe $(1.6 \mathrm{~m})$ than in the upper part $(1.1 \mathrm{~m})$ for the small-scale roughness, which can be explained by the higher activity downslope and is supported by the GPS measurements associated to a higher slope angle and maybe a higher erosion rate. In Harmalière, the roughness is lower in the lower part than in the upper part for both wavelengths. Indeed, since 1981, Harmalière has shown intense activity in its upper part, including collapsing at the headscarp and several minor scarps below that are responsible for a higher large-scale roughness $(5.4 \mathrm{~m})$. The lower part it evolves into a 
more fluent mudslide (large-scale roughness at $2 \mathrm{~m}$ ) related to the development of an accumulation zone that presents a lower slope angle. Similar large-scale roughness values are found for the upper parts of Avignonet and Harmalière. This observation suggests that Avignonet and Harmalière have experienced similar landslide processes in the past. Using roughness as an indicator of landslide activity can however be biased by several factors. The density of data points after filtering the LiDAR data when building the digital surface model (DSM) can influence the roughness. The point density of the terrain surface in forested areas can be too low, resulting in lower roughness values. The effect of farming on altering the surface roughness should also be considered. On a very small scale, farming can decrease the surface roughness; but also largescale roughness could be reduced by farming over decades. On the other hand, if the landslide activity is too high, fields will be abandoned and the roughness will not be further affected. Therefore we can conclude that farming amplifies the trend: smooth areas will be more smoothed and rough areas will stay rough above a certain threshold. In the case of Harmalière, we see from the aerial photos that a lot of fields were abandoned after the 1981 event. Today, farming is completely stopped on Harmalière. Also, the active part in the south of Avignonet was partly farmland in the past and has been abandoned recently.

Taking into account these limitations, the roughness comparison between the Avignonet and Harmalière slides still suggests a significant difference of the recent sliding activity: the Avignonet slide does not show major recent active movements based on the GPS data and aerial photographic analysis, in contrast to the Harmalière slide. Only some areas in the lower part and in the south of Avignonet exhibit small-scale roughness similar to Harmalière. This is consistent with the location of unvegetated areas in the most recent aerial photos, which are correlated to a higher landslide activity.

Regarding slide velocity, values measured by GPS on the Avignonet landslide (Fig. 4) increase from $<20 \mathrm{~mm} / \mathrm{y}$ at the top to $>130 \mathrm{~mm} / \mathrm{y}$ in the most active parts at the toe. The aerial photos show no major signs of activity in Avignonet for the last 50 years with no significant evolution of the headscarp and very small denuded areas. In Harmalière, no GPS measurements are available but, by tracking morphological features through different dates in the aerial photos, one can get an estimate of the average velocity of several meters per year for some parts of the main landslide body, which is significantly higher than in Avignonet.

The comparison of the two landslides using LiDAR data, GPS data, and aerial photos shows that the recent landslide kinematics are highly different. Harmalière seems to be much more active than Avignonet during the past 50 years. A major controlling factor could be the underlying bedrock topography. This possible influence parameter is investigated in the following section.

\subsection{Geophysical investigation}

The H/V measurements were performed at 104 sites (Fig. 6), which were located with a GPS with a horizontal accuracy ranging from one to a few meters under forest. Elevation values were extracted from the LiDAR DEM. The H/V curves (spectral ratio versus frequency) at two sites (S1 and S2) are presented in Fig. 6A. Both curves exhibit a peak with amplitude $>8$ at $0.58 \mathrm{~Hz}$ for $\mathrm{S} 1$ and at $3.63 \mathrm{~Hz}$ for S2, corresponding to the resonance frequency of the site. At S2, a second peak appears at $20 \mathrm{~Hz}$, which could correspond to the resonance of a superficial layer or to a higher resonance mode. The great majority of the 104 measured H/V curves fit the criteria proposed in the SESAME guideline (Koller et al., 2004) for a one-dimensional resonance 
phenomenon, with well-individualized peaks and $\mathrm{H} / \mathrm{V}$ amplitudes $>2$. Only five measurements, located in the southeastern part of the Harmalière landslide (location in Fig. 6B), exhibit a plateau-like shape suggesting two- or three-dimensional effects. This point will be discussed below.

The frequency field was gridded with a kriging algorithm (Kitanidis, 1997) using an exponential variogram model with a $\mathrm{N}-\mathrm{S}$ anisotropy for the search radius. The gridded surface fits the experimental data with an absolute error of $3 \%$. The frequency distribution is presented in Fig. 6C. To the west, this frequency map reveals a NNE-SSW, 500, $\mathrm{m}$ wide, elongated low frequency zone with values ranging from 0.4 to $1 \mathrm{~Hz}$. To the east, frequencies increase rapidly with distance, from 1 to $4 \mathrm{~Hz}$. This eastward evolution of the resonance frequency is consistent with the thinning of the clay layer and the corresponding rise of stiff layers shown in previous works (Crosnier-Leconte et al., 1953; Lambert and Montjuvent, 1968; Blanchet, 1988; Jongmans et al., 2009). Based on the results, using a mean $S$-wave velocity of $600 \mathrm{~m} / \mathrm{s}$ in the clay layer (Méneroud et al., 1995), the clay thickness was calculated between $375 \mathrm{~m}$ to the west and $37 \mathrm{~m}$ to the east. These thickness values are, however, approximate owing to the vertical $S$-wave velocity variation in the clay layer. This results from the effects of compactness and landslide activity. The dynamic characteristics ( $P$-wave and $S$-wave velocities, density) within the different layers (from top to bottom: morainic colluvium, moraine, disturbed clays, undisturbed clays, alluvium, and bedrock) were obtained from previous seismic studies (Méneroud et al., 1995; Renalier et al., 2007; Jongmans et al., 2009) and are presented in Table 2. Thickness values in the layers were estimated at each station from the available geophysical and geotechnical data (Monjuvent, 1973; Antoine et al., 1981; Blanchet, 1988; Lorier and Desvarreux, 2004; Jongmans et al., 2009). Then, the only free parameter left is the thickness of the undisturbed clay layer.

Preliminary theoretical sensitivity tests were conducted using the Sesarray package (Wathelet et al., 2004). They have shown that the clay thickness is the main parameter controlling the resonance frequency. Using the parameters of Table 2, these tests also showed that the impedance contrast between clays and cemented alluvial layers was sufficient enough to generate a peak corresponding to the resonance frequency. It implies that the measured frequency corresponds in each case to the base of the clays. Furthermore, within the slide, no high frequency peak that could sign a shear plane has been recorded nor computed. These results support the use of resonance frequency measurements for determining the base of the clays. On another hand, they indicate that this technique might not be suitable for detecting and mapping the slide itself (Méric et al., 2007). This could be due to an insufficient seismic impedance contrast between the disturbed clays and the undisturbed laminated clays (cf. Table 2).

The unconsolidated material thickness was computed at each station by fitting the theoretical resonance frequency to the measured one using a trial and error method. The plot of computed thicknesses versus experimental resonance periods (inverse of the frequency) for the whole data set shows a good correlation (Fig. 7A), corroborating the determined velocities in the layers. The $\mathrm{H} / \mathrm{V}$ deduced geometry of the seismic bedrock top is compared to the section previously established from a long refraction profile conducted for the study of the Monteynard dam (Blanchet, 1988). This profile, labeled P1 in Fig. 6C, depicts the top of the Jurassic bedrock. A generally good agreement is observed between the two sections (Fig. 7B) in terms of the paleotopography (base of the clay). Detected discrepancies range from a very few meters to the east to some $40 \mathrm{~m}$ to the west. Those may come from changes in the clay layer velocity profile or from uncertainties in the reference geological model established from the refraction study. Other 
errors may also arise from two- and/or three-dimensional effects as well as from varying cementation of the alluvial layers, as observed at outcrop. This prevents the H/V mapping from being exhaustive but allows the relative paleotopography to be estimated and analyzed in terms of geometry.

The thickness values obtained over the whole area were then interpolated using kriging with an exponential variogram model to produce a thickness map of unconsolidated materials (moraines, morainic colluvium, and clays) over the seismic substratum (alluvial compact layers and Jurassic bedrock; Fig. 8A). Outcrops of stiff alluvium and carbonate bedrock ( $0 \mathrm{~m}$ of soft cover thickness) were added in order to better constrain the interpolation. The thickness map is in agreement with the frequency map of Fig. 5, showing a significant westward increase of the clay thickness from $0 \mathrm{~m}$ on the valley flank to more than $300 \mathrm{~m}$ below the village of Sinard. These values are consistent with field observations and the outcropping of the alluvial layers to the east (Fig. 2). This is also consistent with previous estimations (Monjuvent, 1973; Antoine et al., 1981) that give a soft layer thickness from 0 to $300 \mathrm{~m}$ on the west (moraines and clays; Table 2).

Thickness values were subtracted from elevation values given by the LiDAR DEM at each measurement point. The relief of the paleotopography prior to the deposition of the unconsolidated materials is given in Fig. 8B. This palaetopography is very irregular, with elevation variations of more than $150 \mathrm{~m}$. The major feature is the presence of a depression striking NNE-SSW, which is bordered to the East by a N-S ridge culminating at an elevation of about 600 to $620 \mathrm{~m}$ (cross section $\mathrm{AB}$ on Fig. 9). This depression probably coincides with the pre-Würm valley v2 of the paleo Drac River, as suggested by the presence of alluvial outcrops along the lake (Fig. 2) and by previous works (Crosnier-Leconte et al., 1953; Monjuvent, 1973). The N-S ridge appearing to the east and shown on cross section $\mathrm{AB}$ corresponds to the presence of carbonate bedrock irregularly covered with compact alluvial layers and sporadically outcropping along the lakeshore. To the south, this ridge disappears (cross sections AC and AD; Fig. 9). Below the southern part of the Avignonet slide, on its eastern side, the ridge of compact layers extends perpendicular to the overall slide motion and has probably acted as a buttress, preventing catastrophic failure. On the contrary, the Harmalière landslide clearly developed over the lower elevation zone (Fig. 8B); and its motion can be explained by its orientation, which changes from $\mathrm{N}-\mathrm{S}$ to NW-SE in the south.

\section{Discussion and conclusions}

The results show that geophysical investigation with ambient noise measurements allows computing a frequency map (Fig. 6C) that can be converted into a sediment thickness map and a paleotopography map (Fig. 8). Considering the thicknesses that have been computed, one may argue that two- and/or three-dimensional effects are present and that measured frequency values might be biased. Considering the SESAME guideline (Koller et al., 2004), the presence of nonone-dimensional cases has only been evinced in the southeastern part of the Harmalière landslide (Fig. 6C). Another problem arising from calibrations is the eventual presence of lateral $V S$ variations in the soft sediments. Consequently, the soft layer thickness map computed from $\mathrm{H} / \mathrm{V}$ data may contain uncertainties, which could range from a few meters to the east (where the soft layer thickness is of a few tens of meters) to some $40 \mathrm{~m}$ to the west (where the soft layer reaches $300 \mathrm{~m}$ ). The paleotopographic situation of the former Trièves Lake (on which the glaciolacustrine laminated clays were deposited) is irregularly shaped and shows strong lateral variations. 
A N-S ridge to the east of the investigated area, culminates at about $620 \mathrm{~m}$, which disappears to the south. This analysis confirms previous works done by other geophysical methods on Avignonet (Crosnier-Leconte et al., 1953; Blanchet, 1988), and also extends consistently the knowledge of the paleotopography to the south up to Harmalière. The new map also confirms the geological observations and interpretation inferring that several glacial and interglacial erosion phases that took place during the Quaternary (Monjuvent, 1973; Brocard et al., 2003) created a paleotopography marked by the incision of at least two paleovalleys of the Drac, called "Drac de Sinard" and "Drac de Cros", filled with alluvium and running below the laminated clay of the Sinard plateau, notably below Harmalière and Avignonet (Lambert and Montjuvent, 1968; Monjuvent, 1973).

A comparison of the Harmalière and Avignonet landslide kinematics was done based on GPS, aerial photos and LiDAR DEM analysis. The results show that the orientation of the main sliding direction and the level of sliding activity differ greatly for both landslides. The NW-SE axis of the Harmalière slide corresponds to the orientation of the "Drac de Sinard" paleovalley, suggesting that the landslide is controlled by the paleotopography. Regarding the level of sliding activity, a first observation is that the northern part of the Harmalière headscarp is retrogressing to the north and starting to erode the southern flank of the Avignonet slide. The GPS measurements and analysis of digital photographs since 1956 reveal that Harmalière's main slide body is far more active than Avignonet's. The headscarp retreats several meters per year accompanied by a rapid evolution of the denuded area and sliding velocity than can exceed $1 \mathrm{~m} / \mathrm{y}$. In the Avignonet landslide, the 11 years of GPS data do not show velocities exceeding $15 \mathrm{~cm} / \mathrm{y}$. These observations are consistent with the morphology of the landslides (especially the roughness) shown by the Lidar DEM, which reflects more long-term activity. On a W-E profile along the Avignonet slide, Jongmans et al. (2009) observed a negative correlation between the sliding velocity and the $V S$ values of the first $5 \mathrm{~m}$, suggesting a downward increasing deformation state of this clay material. They also found evidence for a slip surface at about 40-m depth within the clay, confirming a previous hypothesis done from inclinometric data (Blanchet, 1988; Lorier and Desvarreux, 2004). When comparing these observations with the position of the ridge in the paleotopography, we can evidence a paleotopographic control of the landslide kinematics. The ridge of hard layers along the eastern part of the Avignonet landslide acts as a buttress that could mechanically prevent the slide from rapid evolution as observed in Harmalière (Fig. 5).

However, the hypothesis of a paleotopography control over the landslide kinematics has to be discussed taking into account a longer time interval than the last 50 years of observation on which it is based. The question is whether the kinematics of the last 50 years are representative for the long term evolution of the two landslides (i.e., over several thousands of years).

Considering (i) the present day topographic profile along the main slope direction of the Avignonet slide, (ii) the position of the ridge at about $700 \mathrm{~m}$ west to the Drac valley with the highest point at about $620 \mathrm{~m}$, and (iii) the initial level of $800 \mathrm{~m}$ asl in which the Drac started to incise, one can say that the possible effects of the paleotopography on the landslide activity did not start at the beginning of the landslide history and may be relatively recent. When the regressive deep slip surfaces started to reach the clay basement, the development of new deeper slip surfaces was obstructed by the ridge. Dating this paleotopography influence is still a challenging question. In the Harmalière slide, the larger depth of the lacustrine deposits was the reason why deep slip surfaces have not yet reached the unconsolidated materials at the base. 
We conclude that paleotopography is a significant controlling factor in landslide activity that can explain the different behavior of two adjacent landslides with apparently similar conditions. Paleotopography may also have another impact on landslide activity as it will influence the hydrogeological conditions within the lacustrine deposits and underlying alluvial deposits in the paleovalleys. This is a topic for further investigation.

\section{Acknowledgements}

We thank the two anonymous reviewers and Richard A. Marston for thorough critical reviews. This work was supported by the European project "Mountain Risks" (Marie Curie program) and the Department of Isère through the Pôle Grenoblois des Risques Naturels. The authors thank F. Renalier, Y. Orengo, and M. Wathelet for their participation with the seismic measurements.

\section{References}

Ambers, R.K.R., 2001, Relationships between clay mineralogy, hydrothermal metamorphism, and topography in a western Cascades watershed, Oregon, USA. Geomorphology 38 (1-2), 4761 .

Antoine, P., Giraud, A., Montjuvent, G., 1981. Les argiles litées du Trièves (Isère) ; conditions de gisement et exemples de propriétés géotechniques. Bulletin de la Société Géologique de France 23, 117-127.

Azanon, J.M., Azor, A., Yesares, J., Tsige, M., Mateos, R.M., Nieto, F., Delgado, J., LópezChicano, M., Martín, W., Rodríguez-Fernández, J., 2009. Regional-scale high-plasticity claybearing formation as controlling factor on landslides in southeast Spain, Geomorphology doi:10.1016/j.geomorph.2009.09.012.

Blanchet, F., 1988. Etude géomécanique de glissements de terrain dans les argiles glaciolacustres de la vallée du Drac. Ph.D. thesis, Université Joseph Fourier, Grenoble, France.

Bozzano, F., Lenti, L., Martino, S., Paciello, A., Scarascia Mugnozza, G., 2008. Self-excitation process due to local seismic amplification responsible for the reactivation of the Salcito landslide (Italy) on 31 October 2002. Journal of Geophysical Research 113, B10312.

Briese, C., Pfeifer, N., Dorninger, P., 2002. Applications of the robust interpolation for DTM determination. In: Proceedings of the ISPRS Technical Commission III Symposium 2002, Graz, Austria. IAPSIS 34 (3A), 55-61.

Brocard, G.Y., Van Der Beek, P.A., Bourlès, D.L., Siame, L., Mugnier, J.L., 2003. Long-term fluvial incision rates and postglacial river relaxation time in the French western Alps from ${ }^{10} \mathrm{Be}$ dating of alluvial terraces with assessment of inheritance, soil development and wind ablation effects. Earth and Planetary Science Letters 209, 197-214.

Chatelain, J.L., Guéguen, P., Guillier, B., Fréchet, Bondoux, F., Sarrault, J., Sulpice, P., Neuville, J. M., 2000. Cityshark: user-friendly instrument dedicated to ambient noise (microtremor) recording for site and building response studies. Seismological Research Letters 71, 698703.

Clark, P.U., Dyke, A.S., Shakun, J.D., Carlson, A.E., Clark, J., Wohlfarth, B., Mitrovica, J.X., Hostetler, S.W., McCabe, A.M., 2009. The Last Glacial Maximum. Science 325 (5941), $710-714$.

Coe, J.A., Ellis, W. L., Godt, J. W., Savage, W.Z., Savage, J. E., Michael, J.A., Kibler, J.D., Powers, P.S., Lidke, D.J., Debray, S., 2003. Seasonal movement of the Slumgullion landslide 
determined from Global Positioning System surveys and field instrumentation, July 1998March 2002. Engineering Geology 68 (1-2), 67-101.

Coe, J.A., McKenna, J.P., Godt, J.W., Baum, R.L., 2009. Basal-topographic control of stationary ponds on a continuously moving landslide. Earth Surface Processes and Landforms 34 (2), 264-279.

Crosnier-Leconte, J., Bordet, C., Duffaut, P., 1953. Séparation de deux anciens lits successifs dans la vallée du Drac à Monteynard (Isère). Comptes-Rendus Sommaires de la Société Géologique de France 12, 221-223.

Cruden, D.M., Varnes, D.J., 1996. Landslide types and processes. In: Turner, A.K., Schuster, R.L. (Eds.), Landslides, Investigations and Mitigations, Transportation Research Board, National Research Council, Special Report 247, pp. 36-75.

Debelmas, J., 1967. La Chapelle-en-Vercors. In: Carte géologique de la France au 1/50000. BRGM Éditions, Orléans, France.

Delgado, J., López Casado, C., Estévez, A., Giner, J., Cuenca, A., Molina, S., 2000. Mapping soft soils in the Segura River valley (SE Spain); a case study of microtremors as an exploration tool. Journal of Applied Geophysics 45 (1), 19-32.

Eilertsen, R.S., Hansen, L., Bargel, T.H., Solberg, I.L., 2008. Clay slides in the Målselv valley, northern Norway: characteristics, occurrence, and triggering mechanisms. Geomorphology 93 (3-4), 548-562.

Flageollet, J.C., Malet, J.P., Maquaire, O., 2000. The 3D structure of the Super-Sauze earthflows: a first stage towards modelling its behaviour. Physics and Chemistry of the Earth 25 (9), $785-791$.

Giraud, A., Antoine, P., Van Asch, T.W.J., Nieuwenhuis, J.D., 1991. Geotechnical problems caused by glaciolacustrine clays in the French Alps. Engineering Geology 31, 185-195.

Glenn, N.F., Streutker, D.R., Chadwick, D.J., Thackray, G.D., Dorsch, S.J., 2006. Analysis of LiDAR-derived topographic information for characterizing and differentiating landslide morphology and activity. Geomorphology 73 (1-2), 131-148.

Guéguen, D., Cornou, C., Garambois, S., Banton, J., 2007. On the limitation of the H/V spectral ratio using seismic noise as an exploration tool: application to the Grenoble valley (France), a small apex ratio basin. Pure and Applied Geophysics 164 (1), 115-134.

Hervas, J., Barredo, J.I., Rosin, P.L., Pasuto, A., Mantovani, F., Silvano, S., 2003. Monitoring landslides from optical remotely sensed imagery: the case history of Tessina landslide, Italy. Geomorphology 54 (1-2), p. 63-75

Huff, W.D., 1974. Mineralogy and provenance of Pleistocene lake clay in an alpine region. Geological Society of America Bulletin 85, 1455-1460.

Ibs-von Seht, M., Wohlenberg, J., 1999. Microtremor measurements used to map thickness of soft sediments. Bulletin of the Seismological Society of America 89 (1), 250-259.

Institute of Photogrammetry and Remote Sensing (IPF)., 2004. Software SCOP++, http://www.ipf.tuwien.ac.at/products/produktinfo/scop.

Jongmans, D., Bièvre, G., Renalier, F., Schwartz, S., Beaurez, N., 2009. Geophysical investigation of the large Avignonet landslide in glaciolacustrine clays in the Trièves area (French Alps). Engineering Geology 109, 45-56.

Kitanidis, P.K., 1997. Introduction to Geostatistics: Applications in Hydrogeology. Cambridge University Press, Cambridge, UK.

Kohv, M., Talviste, P., Hang, T., Kalm, V., Rosentau, A., 2009. Slope stability and landslides in 
proglacial varved clays of western Estonia. Geomorphology 106 (3-4), 315-323.

Koller, M.G., Chatelain, J.L., Guillier, B., Duval, A.M., Atakan, K., Lacave, C., Bard, P.Y., 2004. Practical user guidelines and software for the implementation of the $\mathrm{H} / \mathrm{V}$ ratio technique: measuring conditions, processing method and results interpretation. In: Proceedings of the 13th World Conference in Earthquake Engineering, Canadian Association for Earthquake Engeneering Vancouver, Canada, paper number 3132, $10 \mathrm{p}$.

Konno, K., Ohmachi, T., 1998. Ground-motion characteristics estimated from spectral ratio between horizontal and vertical components of microtremor. Bulletin of the Seismological Society of America 88 (1), 228-241.

Kraus, K., Pfeifer, N., 1998. Determination of terrain models in wooded areas with aerial laser scanner data. ISPRS Journal of Photogrammetry and Remote Sensing 53, $193-203$.

Lambert, A., Montjuvent, G., 1968. Quelques vues nouvelles sur l'histoire quaternaire de la vallée du Drac (note préliminaire). Géologie Alpine 44, 117-138.

Le Roux, O., Schwartz, S., Gamond, J.F., Jongmans, D., Tricart, P., Sebrier, M., 2010. Interaction between tectonic and erosion processes on the morphogenesis of an Alpine valley: geological and geophysical investigations in the lower Romanche valley (Belledonne massif, western Alps). International Journal of Earth Sciences 99, 427-441.

Lorier, L., Desvarreux, P., 2004. Glissement du Mas d'Avignonet, commune d'Avignonet. In: Proceedings of the workshop Ryskhydrogeo, Program Interreg III, La Mure (France), p. 8.

Lundström, K., Larsson, R., Dahlin T., 2009. Mapping of quick clay formations using geotechnical and geophysical methods. Landslides 6, 1-15.

Malet, J.P., Maquaire, O., Calais, E., 2002. The use of Global Positioning System techniques for the continuous monitoring of landslides: application to the Super-Sauze earthflow (Alpes-deHaute-Provence, France). Geomorphology 43 (1-2), 33-54.

Méneroud, J.-P., Duval, A.-M., Vidal, S., Fréchet, J., Gamond, J.-F., Beck, C., Tardy, M., Bard, P.-Y., Barnichon, E., Gaboriaud, J.-M., 1995. Franchissement de l'Ébron, étude de l'aléa sismique local. Tech. Rep. 93/95666/74, CETE Méditerranée, Aix en Provence, France.

Méric, O., Garambois, S., Malet, J.-P., Cadet, H., Gueguen, P., Jongmans, D., 2007. Seismic noise-based methods for soft-rock landslide characterization. Bulletin de la Societé Géologique de France 178 (2), 137-148.

Monjuvent, G., 1973. La transfluence Durance-Isère. Essai de synthèse du Quaternaire du bassin du Drac (Alpes françaises). Géologie Alpine 49, 57-118.

Moulin, C., Chapeau, C., 2004. Le glissement de la Salle en Beaumont (Isère). In: Proceedings of the workshop Ryskhydrogeo, Program Interreg III, La Mure (France), p. 9.

Moulin, C., Robert, Y., 2004. Le glissement de 1'Harmalière sur la commune de Sinard. In: Proceedings of the workshop Ryskhydrogeo, Program Interreg III, La Mure (France), p. 11.

Rankka, K., Andersson-Sköld, Y., Hultén, C., Larsson, R., Leroux, V., Dahlin, T., 2005. Quick Clay in Sweden. Report 65, Swedish Geotechnical Institute, Linköping, Sweden.

Renalier, F., Jongmans, D., Bièvre, G., Schwartz, S., Orengo, Y., 2007. Characterisation of a landslide in clay deposits using $V s$ measurements. In: Near Surface 2007, EAGE Meeting, 03-04 September 2007, Istanbul, Turkey.

Shepard, M.K., Campbell, B.A., Bulmer, M.H., Farr, T.G., Gaddis, L.R., Plaut, J.J., 2001. The roughness of natural terrain: a planetary and remote sensing perspective. Journal of Geophysical Research 106 (E12), 32777-32795.

Vallet, J., Skaloud, J., 2004. Development and Experiences with a Fully-digital Handheld 
Mapping System Operated from Helicopter. The International Archives of the Photogrammetry, Remote Sensing and Spatial Information Sciences XXXV (Commission 5), Part B. ISPR, Istanbul, Turkey.

Van Westen, C.J., Daag, A.S., 2005. Rainfall and lahar-runoff threshold modelling at Mt. Pinatubo, Philippines. Earth Surface Processes and Landforms 30(13), 1663-1674.

Wathelet, M., Jongmans, D., Ohrnberger, M., 2004. Surface-wave inversion using a direct search algorithm and its application to ambient vibration measurements. Near Surface Geophysics 2, 211-221. 


\section{List of Figures:}

Fig. 1. Location of the area and paleogeographical map at the end of the Würm age (adapted from Monjuvent, 1973). Coordinates are in kilometers using the French system Lambert-93. The thick black box shows the location of the study area and the extent of Fig. 2. 1: Laminated clay deposits in the Trièves area; 2: fluvioglacial deposits; 3: extension of the Isère Glacier at the end of the Würm age; 4: present-day topography; L.T.: Lake Trièves; S.B.: La Salle-en Beaumont.

Fig. 2. (A) General view of the Avignonet landslide from the opposite bank of Lake Monteynard (picture taken from location 2a in Fig. 3); (B) Jurassic bedrock overlain by compact, locally cemented alluvial layers; present-day Drac River is at the forefront; (C) compact alluvial layers; (D) laminated clays. Location of the pictures is indicated in Fig. 3.

Fig. 3. Geological map (location in Fig. 1) modified from Debelmas (1967); Lambert and Montjuvent (1968) and cross section modified after Blanchet (1988). Black stars refer to pictures in Fig. 2. Position of cross section $\mathrm{AA}^{\prime}$ is indicated. A: Avignonet landslide; H: Harmalière landslide; MD: Monteynard dam. Below: Geological cross section; v1: first paleovalley ("Drac de Cros"); v2: second paleovalley ("Drac de Sinard"). Dashed line within clays depicts the lower limit of the Avignonet landslide, deduced from inclinometer data. See text for details.

Fig. 4. (A) Shaded LiDAR DEM (light direction is from NW, horizontal resolution of $2 \mathrm{~m}$ ) covering the Avignonet (north) and Harmalière (south) landslides. Dotted lines indicate the landslide limits. The white circles show the position of the GPS points, and the thin straight lines represent the 11-year average horizontal velocity measured by GPS. A1-3 and H1-3 indicate the location of the elevation profiles. (B) Elevation profiles through Avignonet and Harmalière with subdivisions in an upper and lower part. Profiles are $2 \times$ vertically exaggerated.

Fig. 5. Top: Orthorectified aerial photos of the years 1956, 1985, and 2003. The scales of the original photos are 1:25,000, 1:30,000, and 1:25,000. Bottom: Interpretation of the corresponding aerial photo showing the denuded areas related to landslide activity. White areas are not covered by the images. In 1962 the Drac River was dammed, creating the Monteynard Lake shown in the photos from 1985 and 2003. Percentage of denuded area (d) is indicated.

Fig. 6. $\mathrm{H} / \mathrm{V}$ measurements. (A) $\mathrm{H} / \mathrm{V}$ curves at points $\mathrm{S} 1$ and $\mathrm{S} 2$ (location on Fig. 6C). (B) Location of the 104 measurement points with the landslide limits (dashed line); A: Avignonet landslide; H: Harmalière landslide. (C) Resonance frequency map.

Fig. 7. Frequency to thickness calibration for H/V profile P1 (location on Figs. 5B and 5C). (A) Computed thickness as a function of the measured resonance period (inverse of the frequency) for the 104 stations. Linear regression (black dashed line) gives a determination coefficient $r^{2}$ of 0.95 ; (B) Comparison of the geometry of the top of the Jurassic bedrock (Blanchet, 1988) and the bottom of the laminated clays after $\mathrm{H} / \mathrm{V}$ measurements along profile $\mathrm{P} 1$ (location in Fig. 6C). Dashed line depicts the lower limit of the Avignonet landslide deduced from inclinometer data. 
Fig. 8. (A) Thickness maps of the lacustrine deposits. The absolute error between computed and interpolated thicknesses is $5.29 \%$. (B) Lake Trièves paleotopography in the study area. The absolute error between computed and interpolated paleotopography is $0.98 \%$. Dots refer to seismic measurements and crosses to field observations; dashed lines stand for Avignonet and Harmalière landslide limits.

Fig. 9. Cross sections of the paleolake basement (location in Fig. 8B).

Table 1: Root-mean-square deviations from the elevation profiles seen in Figure $4 \mathrm{~b}$ for 2 different wavelengths (step sizes) representing the roughness at different scales. See text for details. * This value is not reliable due to the short profile length.

Table 2: Dynamic characteristics (compressional wave velocity $V p$, shear wave velocity $V s$ and density) used for the calculation of the theoretical resonance frequency (See text for details) 
Figure 1

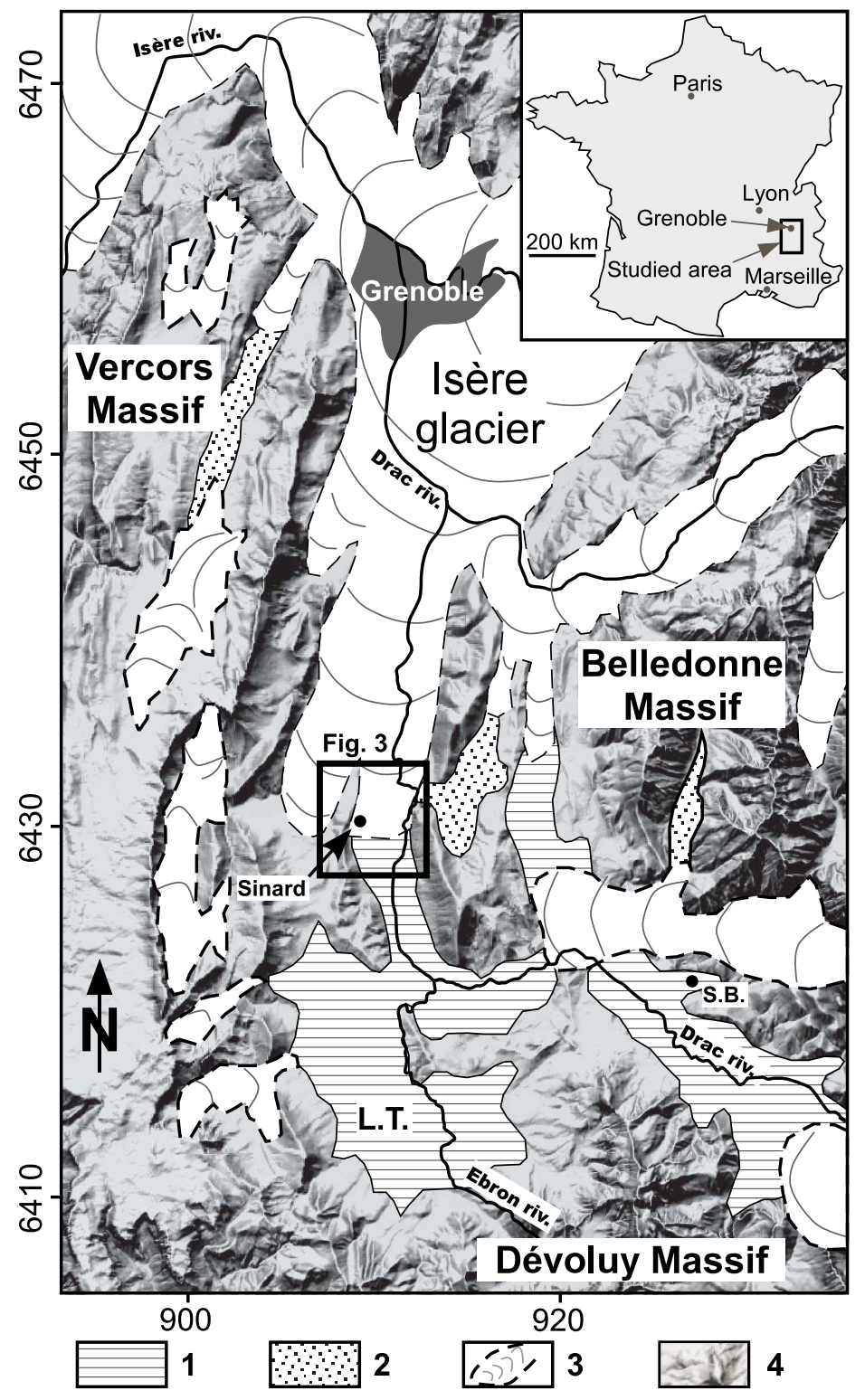


Figure 2

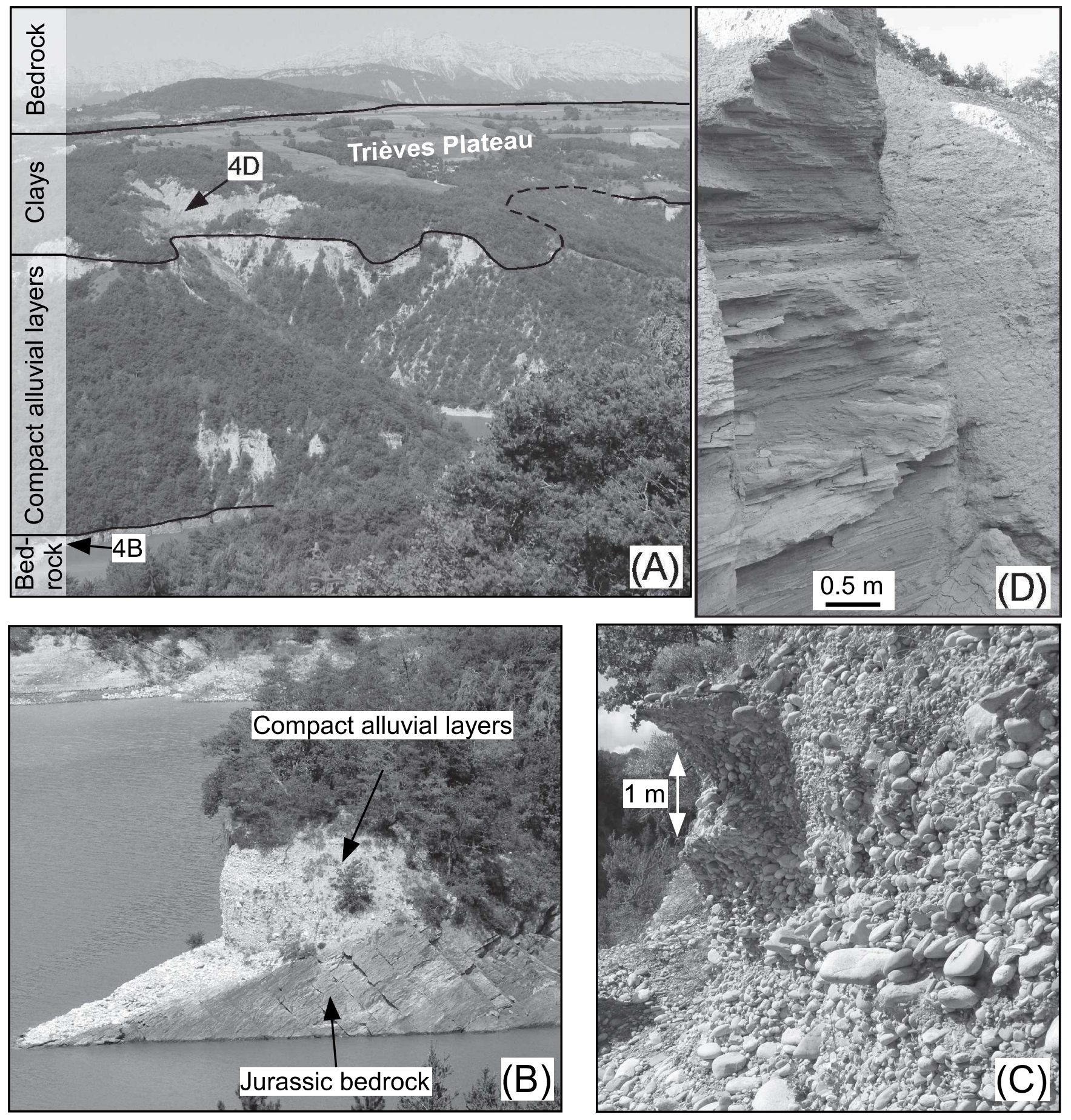


Figure 3
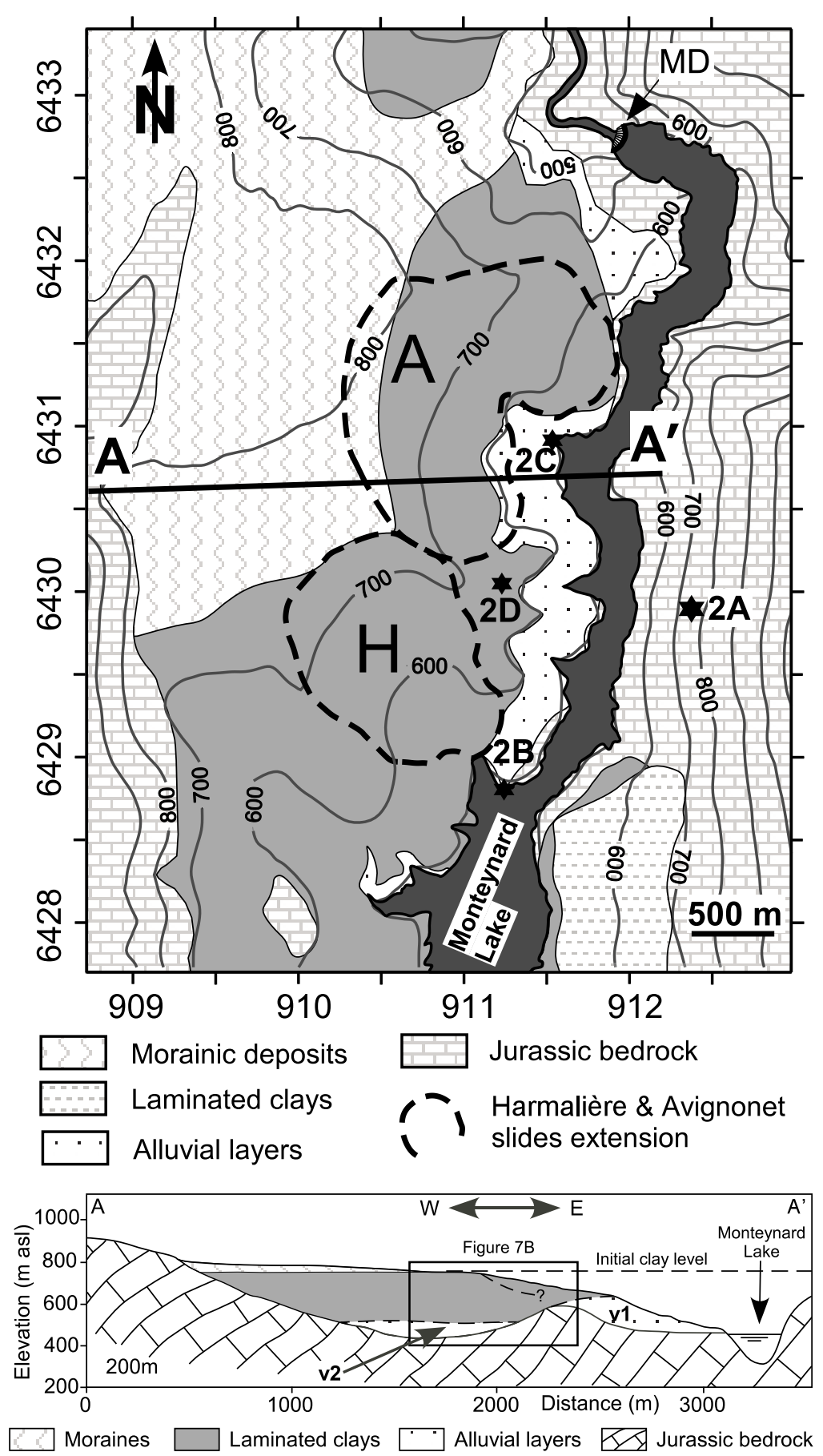
Figure 04

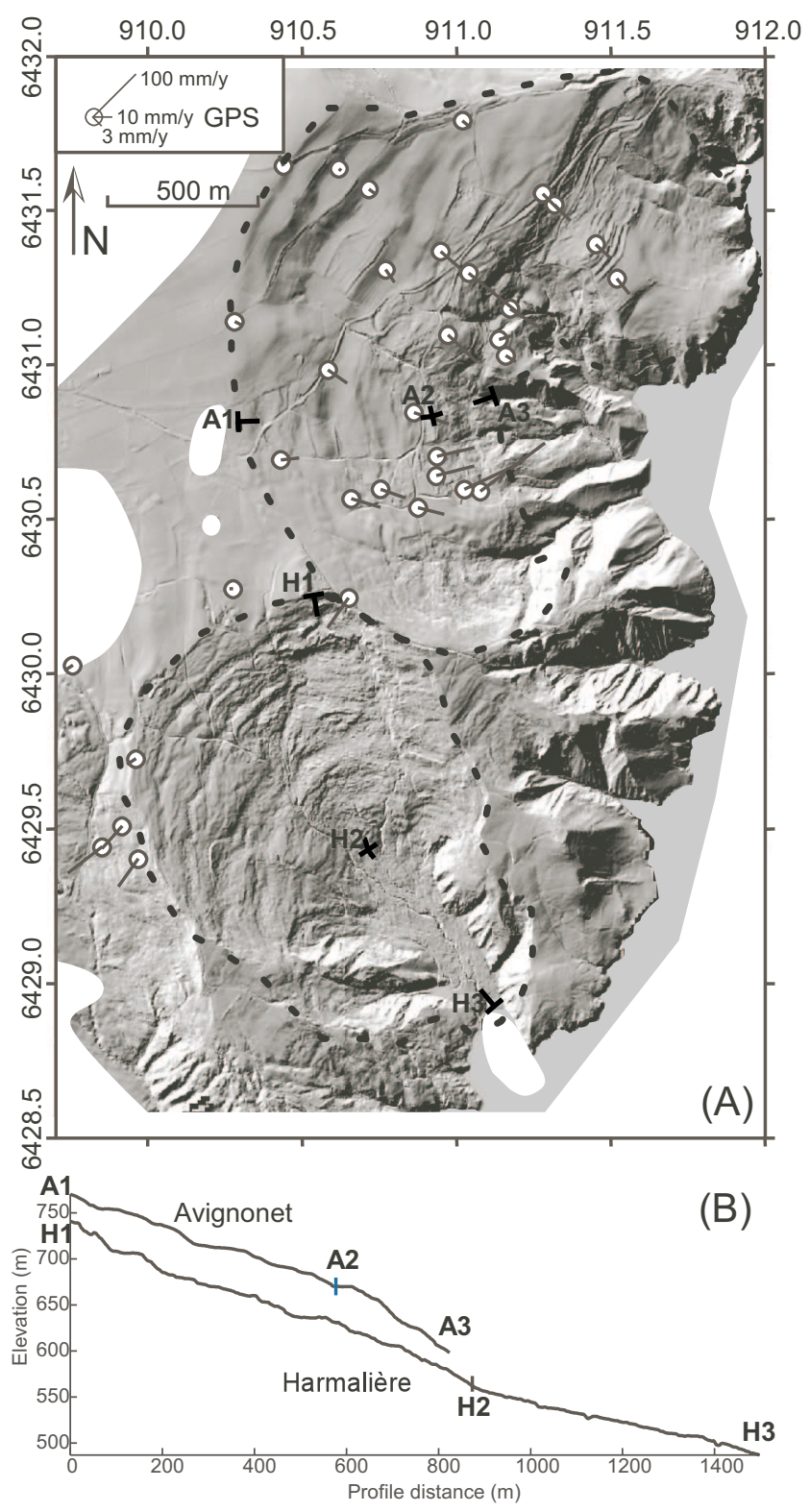


Figure 05

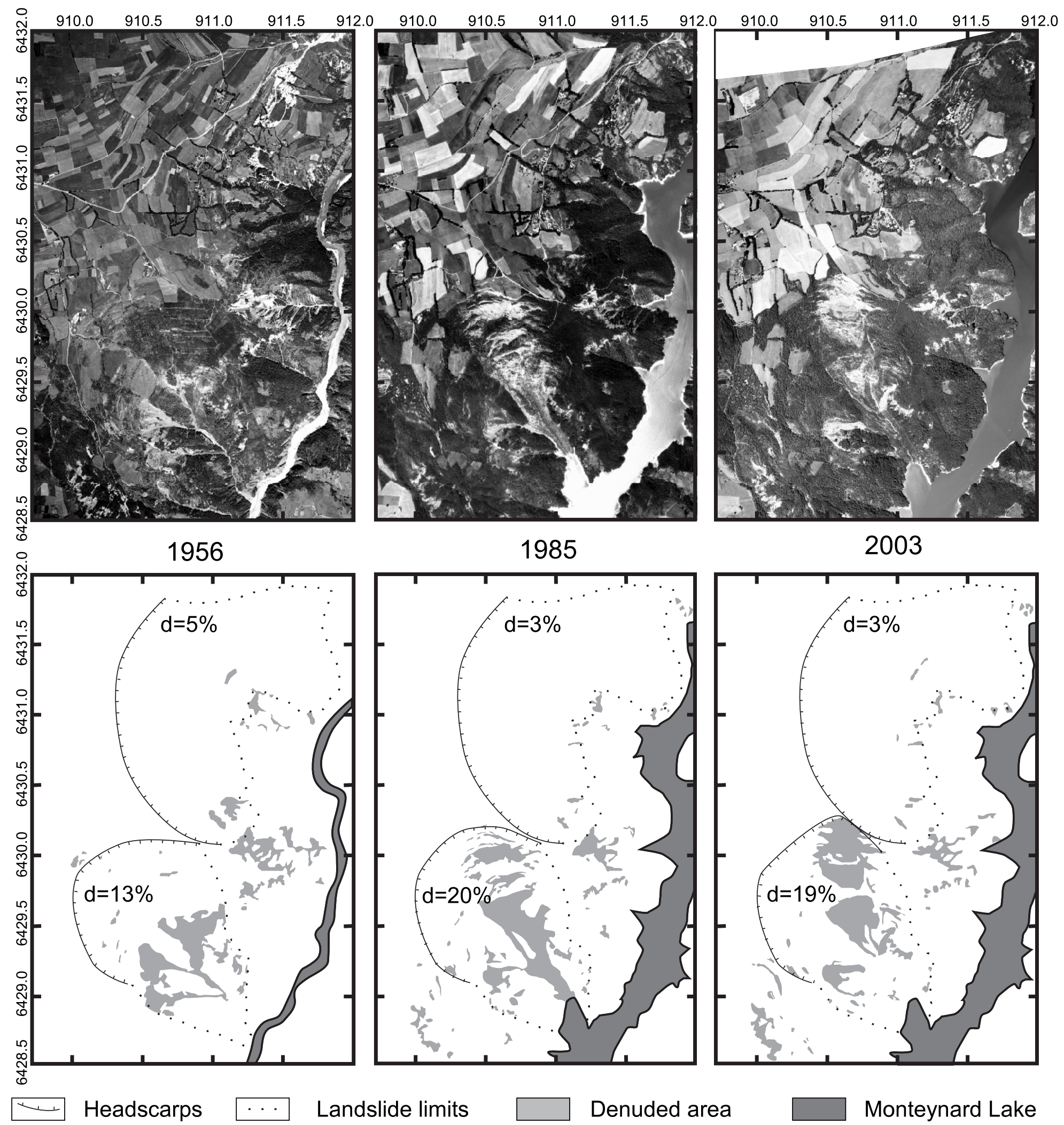


Figure 06
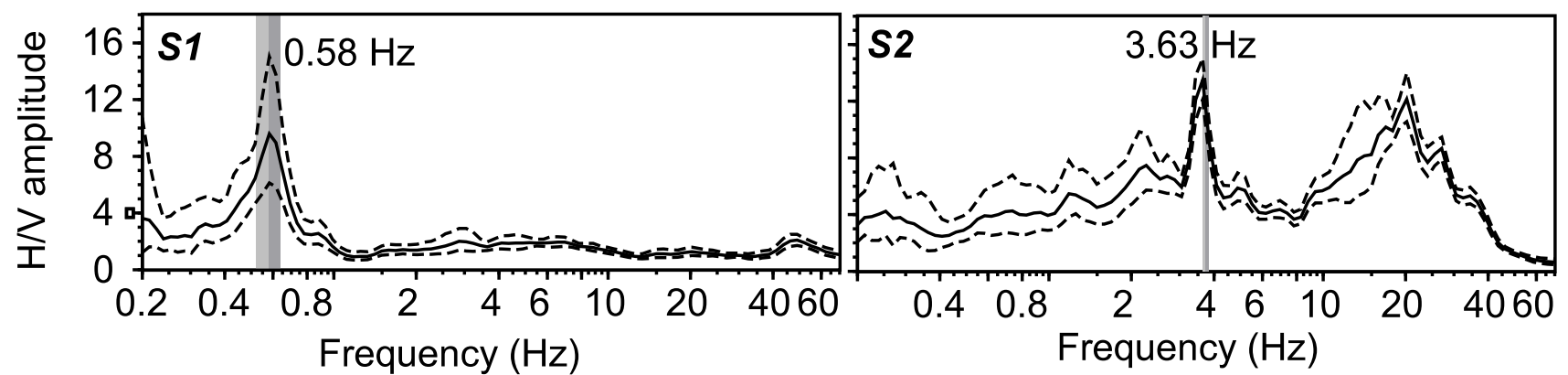
(A) Frequency peak
- Average
-.. Standard deviation
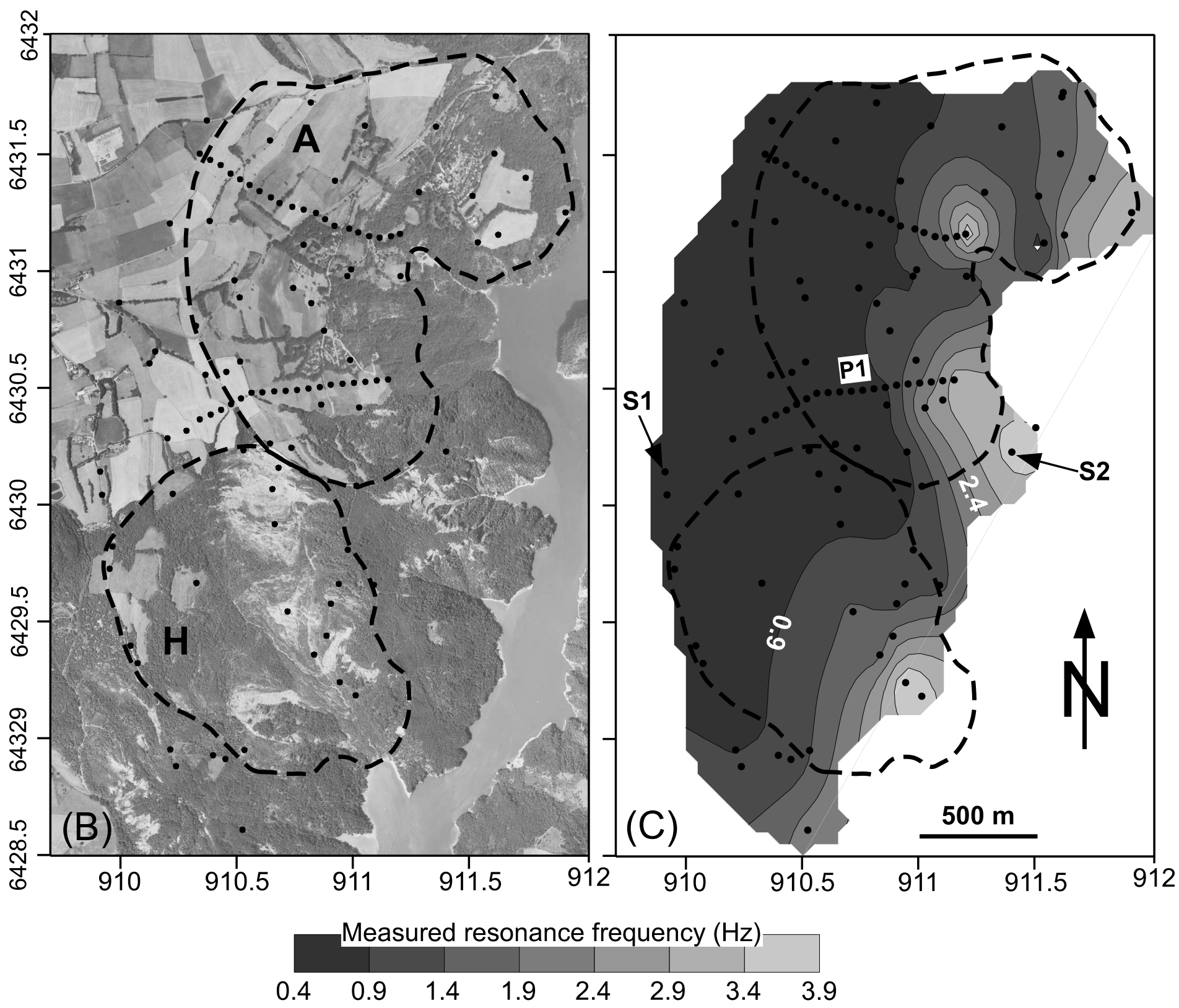
Figure 07
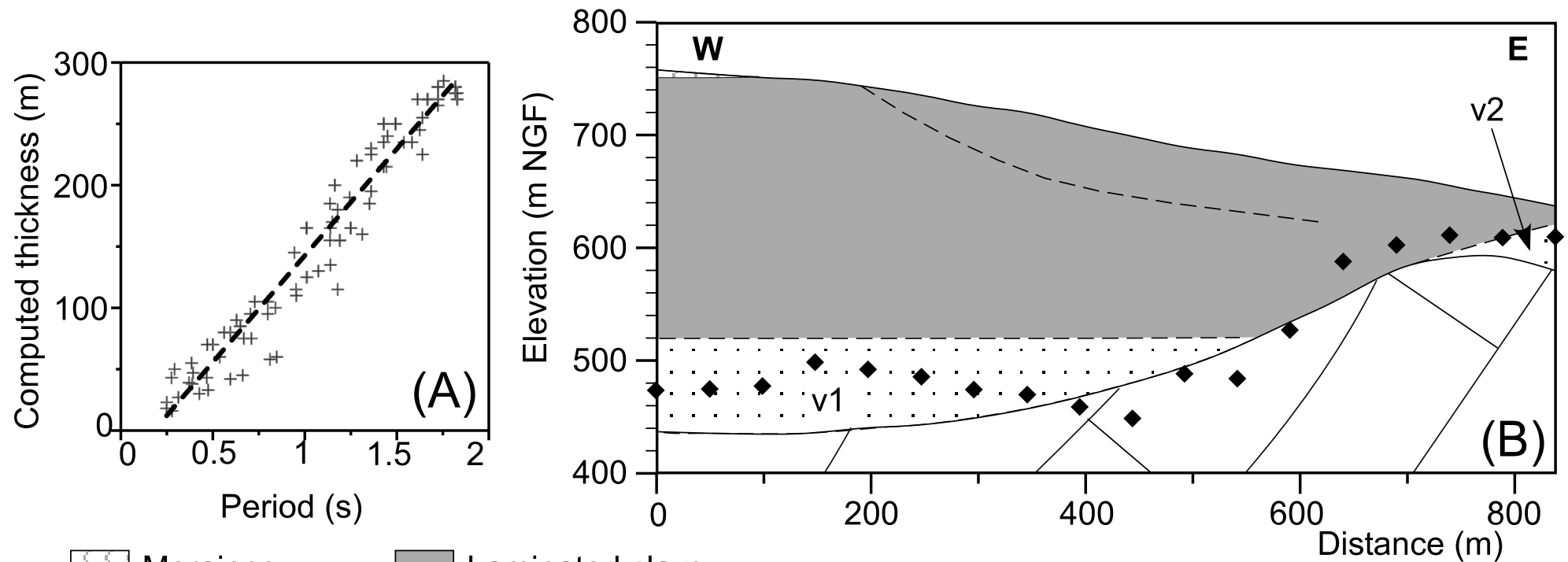

$\square>$ Moraines

$\square$ Laminated clays

$\cdots$ Alluvial layers $\square$ Jurassic bedrock 
Figure 08
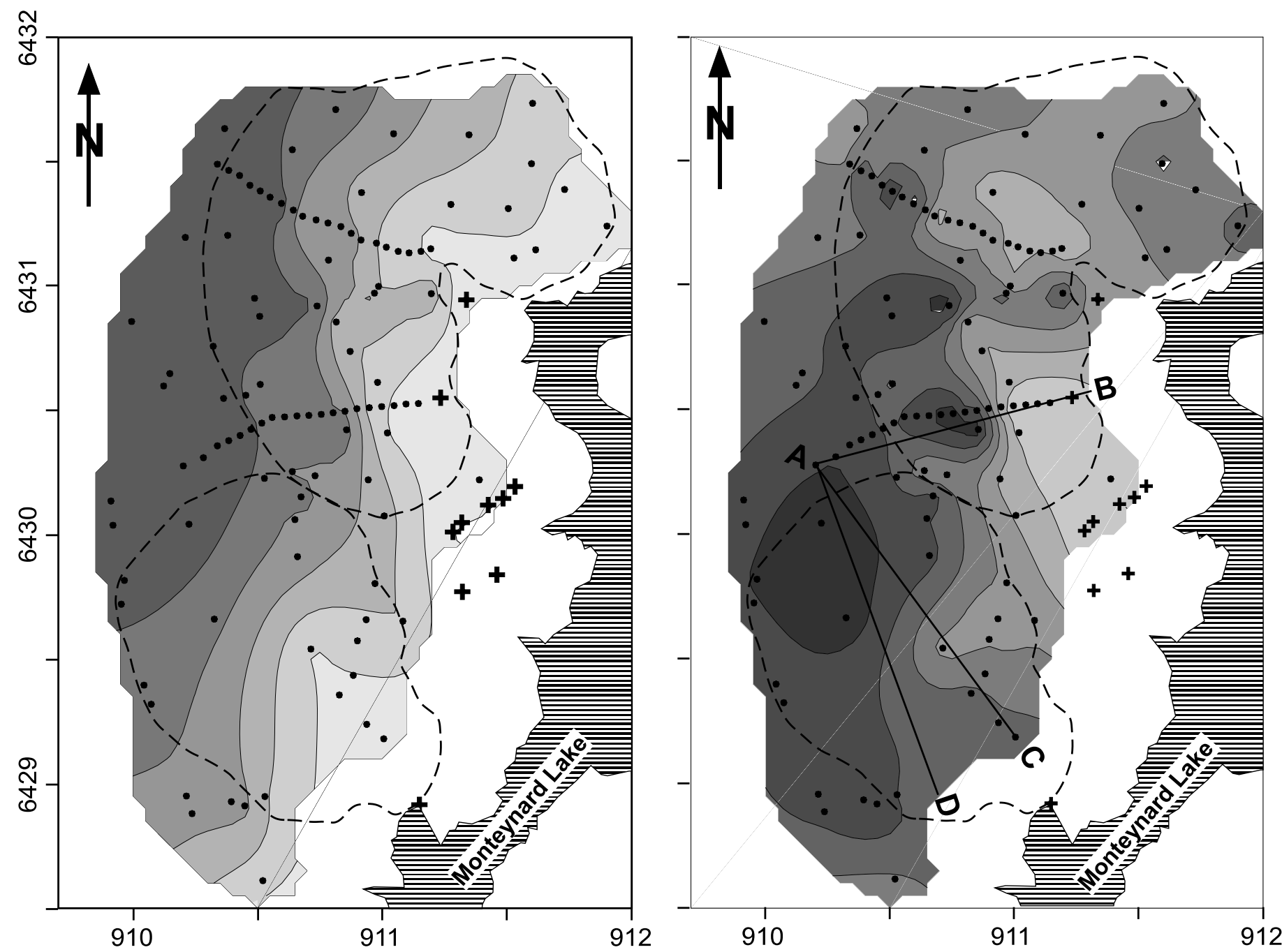

(A)

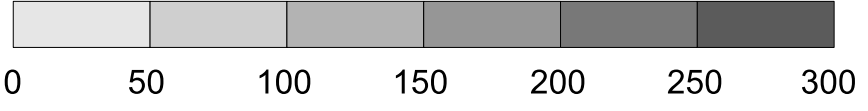
Clays and moraines thickness

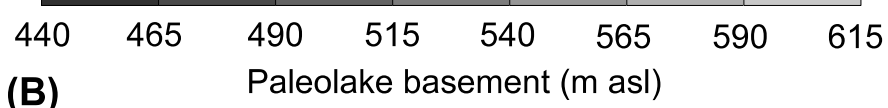


Figure 09

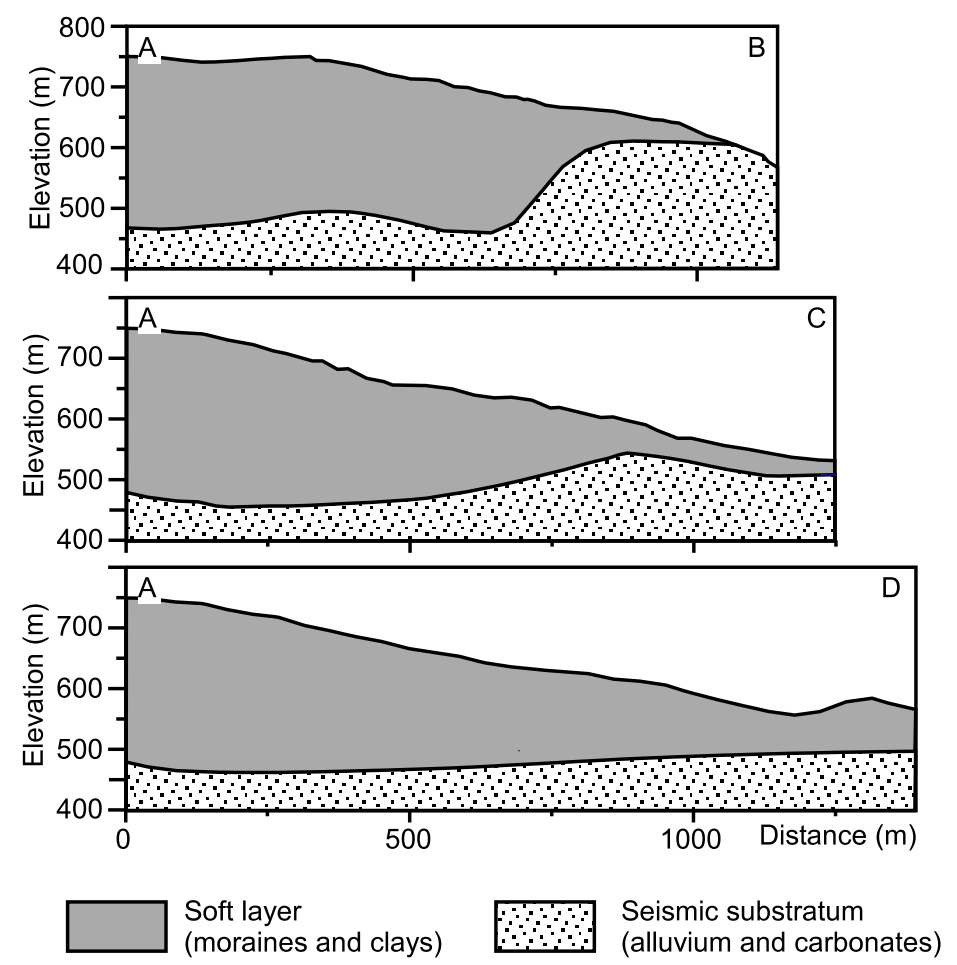


Table 1

Root-mean square deviations from the elevation profiles seen in Fig. 4B for two different wavelengths (step sizes) representing the roughness at different scales (see text for details).

\begin{tabular}{lcccc}
\hline & $\begin{array}{c}\text { A1-A2 upper } \\
\text { Avignonet }\end{array}$ & $\begin{array}{c}\text { A2-A3 lower } \\
\text { Avignonet }\end{array}$ & $\begin{array}{c}\text { H1-H2 upper } \\
\text { Harmalière }\end{array}$ & $\begin{array}{c}\text { H2-H3 lower } \\
\text { Harmalière }\end{array}$ \\
\hline Profile length $(\mathrm{m})$ & 577 & 247 & 874 & 624. \\
Mean slope angle $\left({ }^{\circ}\right)$ & 9.8 & 16.3 & 11.6 & 6.9 \\
RMS deviation $(\mathrm{m})$ small & 1.1 & 1.6 & 1.6 & 1 \\
$\begin{array}{l}\text { scale }(10 \mathrm{~m}) \\
\text { RMS deviation }(\mathrm{m}) \text { large }\end{array}$ & 4.4 & $4.4^{\mathrm{a}}$ & 5.4 & 2 \\
scale $(100 \mathrm{~m})$ & & &
\end{tabular}

a This value is not reliable because of the short profile length.

Table 2

Dynamic characteristics (compressional wave velocity $\mathrm{Vp}$, shear wave velocity $\mathrm{Vs}$, and density) used for the calculation of the theoretical resonance frequency (see text for details).

\begin{tabular}{llccl}
\hline Geological unit & Thickness $(\mathrm{m})$ & $\mathrm{Vp}(\mathrm{m} / \mathrm{s})$ & $\mathrm{Vs}(\mathrm{m} / \mathrm{s})$ & Density \\
\hline Morainic colluvium & 5 & 500 & 250 & 1.9 \\
Moraines & $0-50$ & 1850 & $150-450$ & 2 \\
Disturbed clays & $0-45$ & 1850 & $150-450$ & 2 \\
Unidisturbed clays & $0-250$ & 1850 & $600-650$ & 2 \\
Compact alluvium & $0-100$ & 2350 & 1250 & 2 \\
Carbonate bedrock & Halfspace & 3000 & 2000 & 2.6 \\
\hline
\end{tabular}

